\title{
Institutionalization of Leprosy Researches in Calcutta School of Tropical Medicine (CSTM) and other Programmes from 1920s to $1950 \mathrm{~s}$
}

\author{
Apalak Das* \\ (Received 11 May 2018; revised 23 May 2018)
}

\begin{abstract}
This paper seeks to explore how the institutionalization of leprosy researches in Bengal vis-àvis India took shape in the early half of twentieth century. Some of the revolutionary researches in leprosy, appearing during 1920s-1950s till the implementation of National Leprosy Control Program in 1955, would come under introspection. Along with this, how and to what extent did CSTM, the premier colonial institute succeed in accomplishing its objective and consolidate their researches have been discussed.
\end{abstract}

Key words: CSTM, Institutionalization, Leprosy, Medical research, Tropical disease.

\section{INTRODUCTION}

The word 'Institutionalization' has been used to explain the nature of the functioning of a particular establishment, it largely encompasses the other capricious issues like policymaking, the structure of governance within the institution, resources which are maneuvered, the governing apparatus and the agencies which take the stakes to implement the programs undertaken by the 'Organization' (Morehouse, 1971, pp.1-2). Along with that, the workings of an 'Institution' are largely relied upon the linkages that create an affinity entirely with the social order or with the political, economic and social behavior of society. To Morehouse, Institutionalization, as a concept, is based on a three-dimensional matrix wherein the first dimension deals with the sequential arrangement of an organization of Indian science, and the third dimension considers the 'variables' that might have altered over a period of time as a system of organization and its functional adjustment [the two variables] remolding their internal characteristics. The second dimension on which the paper intends to focus, is concerned with the 'way of knowing' or the process of investigation, operating both internally when it comes to the question of organizing scientific thoughts, and externally through maintaining the relations with the societal divisions (Morehouse, 1971, pp.1-5).

The Scientific Researches which not only probe into the important issues, research gaps or the shortcomings of explorations but also constitute the base of planning, not by default, falls into this category. In order to institutionalize the 'Organization', these [Researches] are the only normative part that holds 'Institution' and 'Society' together. Therefore, the 'Institution' is somewhat different from that of 'organization' which is lacking empirical demeanor. It is pertinent to say that the institution building, which happened to be one of the major intentions of colonial state to systematize the scientific quests in India, was already started in the nineteenth century. Perhaps,

\footnotetext{
* Research Fellow of the Asiatic Society, Kolkata and PhD Scholar, Department of History, Jadavpur University, Kolkata-700032, Email: das.apalak827@gmail.com
} 
the way in which 'Institutionalization of science' was inaugurated in the mid seventeenth century England through the foundation of 'the Royal Society of London' in 1660 (Hunter, 1995, pp. 120-21) had an imprint over the colonial policies regarding institution building in the colonies. As Worboys has pointed out that there was no such thing called 'Imperial science'; instead the scientific explorations should be situated under the wider political and administrative sections 'with separate activities and policies in the dominions, India and colonies'(Kumar ed., 1991, p. 13) the aim of colonial power was to initiate a program to facilitate the scientific researches in the metropolis and peripheries, so that Britain's economic and scientific backwardness relative to Germany and United States could be reduced significantly (Kumar ed., 1991, p. 13). The Imperial science project was, indeed, a failure; although, from 1880's onwards, the utility and universalism of science seemed to have influenced the colonial policies, disciplines and projects, obviously by incorporating more panoptic attitude into it.

Likewise, when germ theory had gradually taken the ground of medical academia by superseding the miasma theory at the second half of the Victorian period, the development of therapeutics, bacteriology, parasitology, virology, laboratory medicine, hospitals ushered a new era in the research of tropical diseases. Needless to say that one of the potential roles of science related to 'constructive imperialism' was to find ultimate solution of environmental and tropical diseases. Wyndham Dunstan, the director of Imperial Institute in London from 1903 to 1924, was of the view that science would be the leading instrument of colonial development. Before Dunstan's idea of colonial progress, Patrick Manson explained the objective of London School of Tropical Medicine, appeared in 1899, that it would be costeffective to the Colonial Government. The perception of Ronald Ross was somehow contrary to Manson. Quite cynically Ross had shown why he was associated with the Liverpool School of Tropical Medicine only because of 'the businessman there would not be slow to learn the great advantages... [for] their plantations, factories and trade of the new knowledge' (Kumar ed., 1991, pp. 16-17). Thus, the institutionalization of disease, whatever the forethought might be, was taking pace when Joseph Chamberlain took over the office of colonial secretary in 1895 (Kumar ed., 1991, p. 15). Meanwhile, some initiatives had been taken by colonial office, for instance in 1904, the Tropical Diseases Research Fund was established and the joint Royal Society/Colonial Office Sleeping Sickness Bureau was inaugurated in 1908; simultaneously the American Public Health Laboratory in Manila was founded in 1902, The Belgium State School of Tropical Medicine in 1906 and the Wellcome Tropical Laboratory came into existence at the Gordon Memorial College in Khartoum (Power, 1996, pp. 198-199). In India, the colonial Government had followed the model of Institutionalization while keeping the idea of 'Enlightened despotism' in its mind. The Pasteur Institute appeared in 1900 in Kasauli which was appropriated as the site for Central Research Institute after receiving official sanction in 1906. At the same time, the King's Institute of Preventive Medicine was inaugurated at Guindy in the Madras Presidency and a Medical Section of the Asiatic Society of Bengal started working in 1906, creating a space for discussing clinical issues (Power, 1996, pp. 199-200). Moreover, with the appointment of Charles Pardey Lukis (18571917) as the Director General of the IMS (Indian Medical Service) in 1910 who was formerly the principal of the Calcutta Medical College and the professor of materia medica, and the enthusiasm of Sir Harcourt Butler which helped in setting up the Indian Research Fund Association (IRFA), the scenario of medical research was changing rapidly (Power, 1996, p. 200).

Hence, the establishment of Calcutta School of Tropical Medicine (CSTM) has to be 
seen as the part of this colonial project in order to orchestrate the researches on tropical medicine in India. It is worth mentioning that the Imperial authority in India wanted to strengthen and broaden its surveillance over the native subjects only after the plague epidemic in 1896, contiguously Leonard Rogers had stressed on having an institution modeled after London or Liverpool School which proved to be effective in tropical disease researches of colonial India and the emerging non-IMS native middle class was gradually steeping forward for political control. In these circumstances, leprosy research in CSTM will be discussed in detail.

\section{Calcutta School of Tropical Medicine (CSTM) ANd Leprosy Researches (1920s-1950s)}

Till mid nineteenth century, Leprosy was neither considered an 'Imperial danger' nor was it a colonial issue. But from the late 1880's, especially after the death of Father Damien in Molokai, the colonial government was thinking of an outright implementation of complete/partial segregation of lepers in the established leper colonies/asylums. This became eventually an 'Imperial concern' intertwined with the spatial governance of native subjects (Bashford, 2004, pp. 81-82). On the other hand, the epidemiologists, public health officers and the government of cape and Australia colonies perceived leprosy as 'Black disease' because of its association with the tropical climate (Bashford, 2004, p. 82). The idea of contagion was developed largely amongst the European populace and eventually it happened to be racially formulated. Emphasis was given to the researches in order to devise public health policies regarding leprosy prevention. Before the foundation of CSTM, there was hardly any institutional research on leprosy in India. Few isolated efforts had been taken concerning leprosy research i.e. The Report on leprosy by the Royal
College of Physicians (1867) was publicly criticized for its conclusion that leprosy was hereditary (Kakar, 1996, p. 217). There was immense controversy relating to the contagiousness of leprosy throughout the last decade of nineteenth century. The Leprosy Commission formed in 1890-91 had expressed unwillingness to segregate 'lepers', but the Government of India (GoI) enacted the 'The Lepers Act 1898, No. III' in which, the provision of isolation was included. ${ }^{1}$ In 1905, when Robert Koch received Nobel Prize, he had supported the theory of isolation for certain contagious diseases, like Tuberculosis and Leprosy (Bashford, 2004, p.88). Whatsoever, these arguments were unable to resolve the prime issue of leprosy treatment until 1920's. Repeated failure of preparing suitable drug, lack of proper organizational approach and increasing number of escapes from the asylums [especially in North India] show that medicinal treatment of leprosy was in a quandary.

Ultimately, Lord Carmichael, the then Governor of Bengal, laid the foundation stone of CSTM on 24 $4^{\text {th }}$ February, 1914 (Power, 1996, p. 206). This had been the first institution which established a full time Leprosy Research Center in the world in 1925 (Dharmendra, 1965, p 753). It was run by the Leprosy Relief Association jointly with the Endowment Fund of the CSTM and IRFA. From the very beginning, the CSTM had to address the aspects of the disease, for example, clinical medicine, therapy, histopathology, bacteriology and epidemiology. The clinicobacteriologic and histologic studies of leprosy focused on the characteristics of lesions, along with that, a special investigation was made on thickened nerves.

The credit for this research went entirely to S N Chatterjee, who was a well-known leprosy worker in the institution (Dharmendra, 1965, p 753). He published articles on this particular topic in the renowned leprosy journals. In one of his

\footnotetext{
1 See The Lepers Act 1898, No. III.
} 
articles, Chatterjee showed that the $33 \%$ leprosy cases of CSTM were due to thickened nerves (Chatterjee, 1933, p 283). Moreover, CSTM had conducted research on hydnocarpus oil [Chaulmoogra oil] and succeeded in preparing low dose schedule of the parent sulfone (DDS). In 1935, CSTM had founded a rural investigation center in a leprosy endemic district of Bengal i.e. Bankura for epidemiological studies (Dharmendra, 1965, p 753). From 1920 onwards, this institute had become a training center of medical men in leprosy. It was, indeed, a brainchild of Leonard Rogers, playing a decisive role in the researches of tropical medicine. He prepared a derivative [soluble sodium salt of the fatty acid] of chaulmoogra oil and injected through intramuscular and intravenous way in 1915 [?] (Chattopadhyay ed., 2000, p.183). But, to Rogers, Ernest Muir was the best qualified man to carry out the leprosy research in India. He was invited by Rogers to be the head of the Leprosy section of CSTM in 1920. His early works in Calcutta were twofold: first of all, foster the improvements in the usage of Chaulmoogra preparations for the injection treatment and secondly, in order to find the actual incidence of leprosy in India with the aim of reducing and controlling the disease, Muir emphasized on extensive house to house surveys in selected areas (Rogers, 1947, pp. 41-43). Moreover, he put more effort in the animal experimentations and histopatholgical studies in CSTM and approached IRFA for funding leprosy surveys in India. ${ }^{2}$ John Lowe, who joined the leprosy research department at CSTM in 1931 and became the head of the department in 1935, had written several articles on 'Sex Incidence of Leprosy', 'Rat Leprosy' and 'Nerve Abscess in Leprosy' during 1930s and 1940s. In his series of experiments on leprosy outdoor patients of CSTM, he found males were more susceptible to the disease than that of females because of their different endocrine functioning (Lowe, 1934,
1937). Both Lowe and Chatterjee, in an effort to avoid surgical treatment, introduced an alternative way of treatment by using intradermal and subcutaneous injections in the affected nerves and tissues (Lowe and Chatterjee, 1938, pp. 543-48). Chatterjee had detected a newer type of leprosy case pertaining to eye appendages which were not widely known to the medical professionals; thus it led to wrong diagnosis (Chatterjee, 1947, pp. 316-19).

In 1936, The Government of Bengal (GoB) decided to send all suspected leprosy cases, mainly those who were government employees, for examination to the concerned presidency or civil surgeon. For further treatment, sometimes the cases were referred to the officer-in-charge of the leprosy department of CSTM. It is evident from the annual report of British Empire Leprosy Relief Association (BELRA), published in 1946, that this Institute received approximately 1,500 leprosy cases annually from all over Bengal of which many of them were supposed to come from government or railway hospitals and industrial belts of the province (Ray, 1998, p. 88). Dharmendra was of the opinion that the infrastructures or facilities for training of leprosy workers provided by the institute seemed not only to be utilized by the medical professionals in India, but also by the people from outside India (Dharmendra, 1965, p. 754). On contrary, the report of Bengal Public Health Department in 1940 presented a different picture; the work of CSTM, according to the report, was largely impeded by the undersupply of sufficient accommodation for the post-graduate students who were likely to pursue their careers as tropical diseases researchers. The GoB also criticized the way in which the research scholars were trained under each department, lacking a broad plan of action. ${ }^{3}$ Whatsoever, Dharmendra, though the infrastructure of the institution was not so impressive compared

\footnotetext{
2 See file no. 196/27, DGIMS, Public Health (Sanitary), 1927, National Archives of India (NAI)

3 See B C Roy Collection, subject file, 239, 1940, Nehru Memorial Museum and Library (NMML).
} 
to the Liverpool or London School, continued his researches within this four walls till the mid-1950s. While doing his research on lepromin test, Dharmendra got interested in the ancient samhit $\bar{a}$ and smrti texts and terminologies regarding leprosy and tried to give references of ancient system of medications in the hypothesis concerning the medical research on leprosy whenever possible (Dharmendra, 1947, pp. 424-28). The CSTM had finally succeeded in getting rid of the tag of peripheral institution after 1947 and become one of the major medical research institutes in post-independent India. From 1950 to 1955 , Dharmendra and his research associates published their findings in various journals. In order to prepare an alternative medicine instead of using sulfone derivatives which had toxic elements, Dharmendra with his associates made a mixture of sulphetrone with hydnocarpus oil after examining almost 80 lepromatous in-patients in the CSTM (Dharmendra, Dey, Bose \& Kapur, 1950, pp. 309-31). In 1954, he wrote, with his colleagues, an article on comparative study of three Antigens for lepromin test showing that Dharmendra Antigen (DM) was giving positive early reactions 'with the same frequency as the positive late reactions of the classical Mitsuda antigen'(Dharmendra, Mukerjee \& Khoshoo, 1954, pp. 311-21). This proved to be major discovery in the history of leprosy research indeed.

\section{Conclusion}

The foundation of CSTM, as one of the premier and leading tropical disease research institutes, was a feather in colonial cap, heightening the necessity of medical research in colonial medicine from early twentieth century. Helen Power has rightly contemplated that this school was borne out of collective involvement; the GoB and GoI, the Indian medical practitioners from emerging English educated middle class and IMS officers, altogether were associated with this institution from its inception. It is also true that the leprosy researches in colonial periphery took shape only after the establishment of CSTM, but the major impediment which affected the research works was lack of funding either from GoB or GoI, even sometimes BELRA (Indian Council) could not provide the financial assistance to the research projects taken by the faculties. In 1919, the administration of CSTM had become provincial issue under GoI Act propping up the idea that British government intended to retain control over colonial public health system in India without taking liabilities of the institution. Moreover, Rogers's opinion for De-Indianizing IMS and acquiring the Institution as All India Research Institute was a lone voice in the wilderness (Power, 1996, 212-14). Whatever the situation was, the leprosy researches done by the medical protagonists during 1920 s to 1950 s did at least set wheels in motion which proved to be defunct recently. Under LCDC (Leprosy Case Detection Campaign) program of 2017, nine leprosy cases have been detected in a single village of South 24 Parganas, West Bengal which unveil the paucity of medical researches, of social awareness programs and of monitoring over the incidence and prevalence rate in recent decades. ${ }^{4}$ The LCDC Report of 2016 shows that in 20142015 , total 1, 25,785 new leprosy cases were detected in India. ${ }^{5}$ Therefore, in order to situate the point of departure in leprosy research we must

\footnotetext{
${ }^{4}$ A survey has been recently conducted by the District Health and Family Welfare Committee, South 24 Parganas, West Bengal under LCDC Program of 2017, during $6^{\text {th }}-9^{\text {th }}$ November in which 9 leprosy patients are detected in a single village South Khargachi, P.O- Govindapur, Police Station -Bhangar, South 24 Parganas, Pin-743502. Out of those 9 patients, 5 patients are $<50$ years. I would like to pay my gratitude to Mr. Mamtajul Haque Laskar, who is a Para-teacher of Bodra High School and his wife Mrs. Momotaz Bibi, who is ICDS (Integrated Child Development Services) worker, helping me by providing necessary information about the status of LCDC Program in their village. Due to the lack of ASHA workers, they have been assigned to this program in the district level

5 See the Report of LCDC, 2016.
} 
turn back to the period between 1920s - 1950s, reaching its peak with the commencement of National Leprosy Control Program (NLCP) in 1955.

\section{BIBLIOGRAPHY}

Bashford, Alison. Imperial Hygiene: A Critical History of Colonialism, Nationalism and Public Health, Palgrave Macmillan, New York, 2004.

Bhattacharya, Nandini. Contagion and Enclaves: Tropical Medicine in Colonial India, Liverpool University Press, Liverpool, 2012, pp. 1-7.

Chatterjee, S N. Thickened Nerves in Leprosy in relation to Skin Lesions, International Journal of Leprosy, 1.3(1933): 283-92.

Chatterjee, S N. Leprosy of the Eyes and its Appendages, International Journal of Leprosy, 15.3(1947): 316-19.

Chattopadhyay, D P. (ed.), History of Science, Philosophy and Culture in Indian Civilization, Vol. 9, Part1, OUP, New Delhi, 2000.

Dharmendra. Leprosy Research in India, International Journal of Leprosy, 33.3 (1965):752-58.

Dharmendra. Leprosy in Ancient Indian Medicine, International Journal of Leprosy, 15. 4(1947):424-28.

Dharmendra; Dey, Bose, N C R and Kapur, P L. The Intramuscular administration of Sulphetrone in the treatment of Leprosy, International Journal of Leprosy, 18.3(1950): 309-31.

Dharmendra, Mukerjee, N and Khoshoo, P N. A Comparative Study of Three Antigens for the Lepromin Test, International Journal of Leprosy, 22.3 (1954):311-21.

Hunter, Michael. Science and the Shape of Orthodoxy: Intellectual Change in Late Seventeenth-Century Britain, The Boydell Press, Woodbridge, 1995.

Jaggi, O P. Medicine in India: Modern Period, in D.P Chattopadhyay (ed.) History of Science, Philosophy and Culture in Indian Civilization, Vol. 9, Part 1, OUP, New Delhi, 2000.
Kakar, Sanjiv. Leprosy in British India, 1860-1940: Colonial Politics and Missionary Medicine, Medical History, 40.2 (1996): 217.

Kumar, Deepak (ed.) Science and Empire: Essays in Indian Context (1700-1947), Anamika Prakashan, Delhi, 1991.

Lowe, John. The Sex Incidence of Leprosy, International Journal of Leprosy, 2.1 Jan-Mar (1934):57-72.

Lowe, John. A Further note on Abscess in Leprosy, International Journal of Leprosy, 2.3, Aug-Oct, (1934): 301-03.

Lowe, John. Rat Leprosy: A Critical Review of the Literature, International Journal of Leprosy, 5.3 (1937):311-28, 446

Lowe, John and Chatterjee. Experiments in the Treatment of the Trophic Lesions of Leprosy by injections of Hydnocarpus preparations, International Journal of Leprosy, 6.4 (1938):543-48.

Morehouse, Ward. Science in India: Institution Building and the Organizational System for Research and Development, Popular Prakashan, Bombay, 1971.

Polu, Sandhya L. Infectious Disease in India, 1892-1940: Policy making and the Perception of Risk, Palgrave Macmillan, England, 2012, pp. 2-22.

Power, Helen. The Calcutta School of Tropical Medicine: Institutionalizing medical Research in the Periphery, Medical History, 40.2 (1996):198-199.

Ray, Kabita. History of Public Health: Colonial Bengal 1921-1947, K P Bagchi \& Co., Calcutta, 1998.

Rogers, Leonard. Note on the Earlier Work on Leprosy of Dr. Ernest Muir, Leprosy Review, 18. 2/3(1947): 4143

The Operational Guidelines of Leprosy Case Detection Campaign (LCDC) of 2016, Central Leprosy Division, Directorate General of Health Services Ministry of Health and Family Welfare Government of India.

Worboys, Michael. Science and the Colonial Empire, 18951940, in Deepak Kumar (ed.) Science and Empire: Essays in Indian Context (1700-1947), Anamika Prakashan, Delhi, 1991. 